\title{
The effect of amino-acid-supplemented wheat gluten on cholesterol metabolism in the rat*
}

\author{
BY M. BASSAT AND S. MOKADY $\dagger$ \\ Department of Food Engineering and Biotechnology Technion, Haifa, 32000, Israel
}

(Received 27 October 1983 - Accepted 27 July 1984)

1. The effect of lysine- and threonine-supplemented wheat gluten on cholesterol metabolism was studied using male weanling rats. Animals were fed on cholesterol-free diets containing 100 or $200 \mathrm{~g}$ gluten $/ \mathrm{kg}$ with or without amino acid supplementation, and compared with animals given 50,100 and $200 \mathrm{~g}$ casein $/ \mathrm{kg}$ diets, for 3 weeks.

2. A hypocholesterolaemic effect observed with the wheat gluten-fed rats, compared with the animals given 100 and $200 \mathrm{~g}$ casein $/ \mathrm{kg}$ diets, was accompanied by increased turnover of cholesterol as expressed by enhanced cholesterol biosynthesis and increased faecal excretion of cholesterol and bile acids. This effect was not abolished by lysine and threonine supplementation.

3. Low levels of blood cholesterol were also observed in the rats fed on the $50 \mathrm{~g}$ casein $/ \mathrm{kg}$ diet. However, a different mechanism, related to impairment of cholesterol transport from the liver, was most likely responsible for the hypocholesterolaemia found in these protein-malnourished animals.

4. The effect on cholesterol metabolism produced by dietary wheat gluten was independent of the low quality of the protein and of its specific deficiency in lysine and threonine.

Dietary wheat gluten has been shown to exert a hypocholesterolaemic effect in growing rats compared with rats fed on a control casein diet. The low serum cholesterol levels were apparent in rats fed on diets containing $100 \mathrm{~g}$ gluten $/ \mathrm{kg}$ which were either cholesterol-free (Mokady \& Einav, 1978) or cholesterol-supplemented atherogenic diets (Mokady \& Liener, 1982). The atherogenic diets were provided with or without supplementation of lysine and threonine which are the limiting amino acids of wheat gluten. The results indicated that the hypocholesterolaemic effect of dietary wheat gluten was independent of its low lysine content and low lysine: arginine value. This is in disagreement with Kritchevsky (1979), and Balogun et al. (1982) who suggested that the hypocholesterolaemic effect of soya-bean protein is related to its low lysine:arginine value.

The low levels of serum cholesterol exhibited by the rats fed on the cholesterol-free wheat gluten diets were accompanied by enhanced hepatic lipogenesis and cholesterol synthesis (Mokady \& Einav, 1978) and were attributed to increased faecal excretion of cholesterol and bile acids (Einav et al. 1981). No studies were undertaken to evaluate the effect of lysine and threonine supplementation on these aspects of cholesterol metabolism. In addition, it should be noted that the rats fed on the unsupplemented gluten diets suffered from severe protein malnutrition, a state previously shown by Tripathy et al. (1970) to be associated with hypocholesterolaemia. Thus, in our previous studies, the specific effect of gluten on cholesterol metabolism could not have been clearly distinguished from the effect caused by malnutrition. It was therefore of interest to evaluate the effect of lysine-and threoninesupplemented wheat gluten and, separately, the effect of protein malnutrition, on cholesterol metabolism, and thereby gain a better insight into the factors affecting the mechanisms responsible for the hypocholesterolaemic effects of wheat gluten.

\footnotetext{
* A preliminary part of the study was presented at the XXII International Conference on Biochemistry and Lipids, Milan, 1980.

$\dagger$ For reprints.
} 


\section{METHODS \\ Animals and diets}

Male weanling rats, $23 \mathrm{~d}$ old, weighing 63-65 g, were of the Charles-River CD strain. The animals, divided into groups of eight, were housed in individual cages and provided with diets containing 100 or $200 \mathrm{~g}$ casein or wheat gluten $/ \mathrm{kg}$ for 3 weeks. The wheat gluten diets were administered with or without supplementation of 9 or $6.5 \mathrm{~g} \mathrm{~L}$-lysine hydrochloride and 2.8 or $0.3 \mathrm{~g} \mathrm{~L}$-threonine $/ \mathrm{kg}$ to the 100 or $200 \mathrm{~g}$ protein $/ \mathrm{kg}$ diets respectively, to meet the dietary requirements of growing rats (Rama-Rao et al. 1959). An additional group of rats received a $50 \mathrm{~g}$ casein $/ \mathrm{kg}$ diet which was designed to simulate protein malnutrition to an extent similar to that caused by the $100 \mathrm{~g}$ gluten $/ \mathrm{kg}$ diet as apparent by growth retardation. The basic diet was according to the Association of Official Agricultural Chemists (1970) as described previously (Mokady \& Einav, 1978).

\section{Experimental}

At the end of the feeding period, the animals were weighed and starved overnight. Blood was collected by means of heart puncture and livers and adrenals removed and weighed. The livers were immediately inserted into ice-cold saline ( $9 \mathrm{~g}$ sodium chloride/1) for the measurement of total lipids and cholesterol biosynthesis, as expressed by $\left[1-{ }^{14} \mathrm{C}\right]$ acetate incorporation into liver slices (Mokady \& Einav, 1978). Such in vitro studies give the maximal biosynthetic capacity of the tissue. Faeces were collected for $48 \mathrm{~h}$ before the starvation period.

\section{Analytical methods}

Lipids of faeces and livers were extracted according to Folch et al. (1957) and the cholesterol content in the lipid fraction as well as that in the serum samples were determined after saponification by the method of Rudel \& Morris (1973). Faecal bile acids were determined by the method of Singer \& Fitschen (1961).

\section{Statistical analysis}

Values were analysed statistically by the BMDO7V multiple-range test (Dixon, 1971).

\section{RESULTS}

\section{Growth performance indices}

The results showing the effects of the various diets on body-weight, food consumption and relative weights of livers and adrenals, at the end of the 3-week feeding period, are presented in Table 1. Body and liver weights of the animals correlated with the nutritional value of the diets and were independent of the dietary protein source. Rats fed on the $100 \mathrm{~g}$ gluten $/ \mathrm{kg}$ diet and those fed on the diet containing $50 \mathrm{~g}$ casein $/ \mathrm{kg}$ were malnourished to the same extent as shown by similar growth retardation. High values for the adrenals'relative weight, which are indicative of protein malnutrition (Einav et al, 1981) were obtained for the rats given 100 and $200 \mathrm{~g}$ gluten $/ \mathrm{kg}$ diet and $50 \mathrm{~g}$ casein $/ \mathrm{kg}$ diet, as compared with those found for the animals of the other dietary groups. The similar body-weights and organ weights observed for the rats fed on $100 \mathrm{~g}$ gluten or $50 \mathrm{~g}$ casein $/ \mathrm{kg}$ diets enabled assessment of the role of protein malnutrition in cholesterol metabolism.

\section{Liver lipogenesis and cholesterol synthesis}

Fig. 1 shows the effect of the various diets on liver lipogenesis and cholesterol synthesis as expressed in vitro $\left[1-{ }^{14} \mathrm{C}\right]$ acetate incorporation into liver slices. Enhanced hepatic lipogenesis 
Table 1. The effects of gluten and casein diets on food intake and body-, liver and adrenal weights after 21 d feeding

(Mean values with their standard errors for eight rats per dietary group)

\begin{tabular}{|c|c|c|c|c|c|c|c|c|}
\hline \multirow{2}{*}{$\begin{array}{l}\text { Dietary protein } \\
(\mathrm{g} / \mathrm{kg})\end{array}$} & \multicolumn{2}{|c|}{ Body-wt* $(g)$} & \multicolumn{2}{|c|}{ Food intake (g) } & \multicolumn{2}{|c|}{$\begin{array}{c}\text { Liver wt } \\
\text { (g/kg body-wt) }\end{array}$} & \multicolumn{2}{|c|}{$\begin{array}{c}\text { Adrenal wt } \\
(\mathrm{mg} / \mathrm{kg} \text { body- } \mathrm{wt})\end{array}$} \\
\hline & Mean & $S E$ & Mean & SE & Mean & $\mathrm{SE}$ & Mean & SE \\
\hline \multicolumn{9}{|l|}{ Gluten: } \\
\hline 100 & $74 \cdot 6$ & $3 \cdot 2$ & $182 \cdot 1$ & 6.9 & $34 \cdot 0^{\mathrm{a}}$ & $2 \cdot 5$ & $227^{\mathrm{ab}}$ & 19 \\
\hline $100+$ supplement $\dagger$ & $148 \cdot 0$ & $6 \cdot 4$ & 287.0 & $8 \cdot 0$ & $39 \cdot 8^{\mathrm{ab}}$ & 0.7 & $141^{\mathrm{ed}}$ & 7 \\
\hline 200 & $103 \cdot 2$ & $2 \cdot 0$ & 252.4 & $12 \cdot 2$ & $40 \cdot 3^{2 b}$ & 0.4 & $194^{b c}$ & 12 \\
\hline $200+$ supplement & $186 \cdot 7$ & $3 \cdot 8$ & $296 \cdot 2$ & $7 \cdot 7$ & $46 \cdot 0^{\mathrm{b}}$ & $2 \cdot 5$ & $116^{\mathrm{d}}$ & 12 \\
\hline \multicolumn{9}{|l|}{ Casein: } \\
\hline 50 & $71 \cdot 0$ & $2 \cdot 1$ & $162 \cdot 0$ & $13 \cdot 0$ & $32 \cdot 0^{\mathrm{a}}$ & $2 \cdot 0$ & $288^{\mathrm{a}}$ & 47 \\
\hline 100 & $126 \cdot 0$ & $3 \cdot 6$ & 262.0 & $5 \cdot 1$ & $38 \cdot 0^{\mathrm{ab}}$ & 1.9 & $139^{d}$ & 8 \\
\hline 200 & $183 \cdot 5$ & $7 \cdot 4$ & 284.0 & $10 \cdot 9$ & $46 \cdot 0^{\mathrm{b}}$ & $4 \cdot 8$ & $120^{\mathrm{d}}$ & 13 \\
\hline
\end{tabular}

a, b, c, d Values in the same vertical column not sharing a common superscript letter differed significantly $(P<0.05)$.

* Initial body-wt $63-65 \mathrm{~g}$

† Supplemented with $9 \mathrm{~g}$ L-lysine hydrochloride and $2.8 \mathrm{~g} \mathrm{~L}$-threonine $/ \mathrm{kg}$.

$\ddagger$ Supplemented with $6.5 \mathrm{~g} \mathrm{~L}$-lysine hydrochloride and $0.3 \mathrm{~g} \mathrm{~L}$-threonine $/ \mathrm{kg}$.

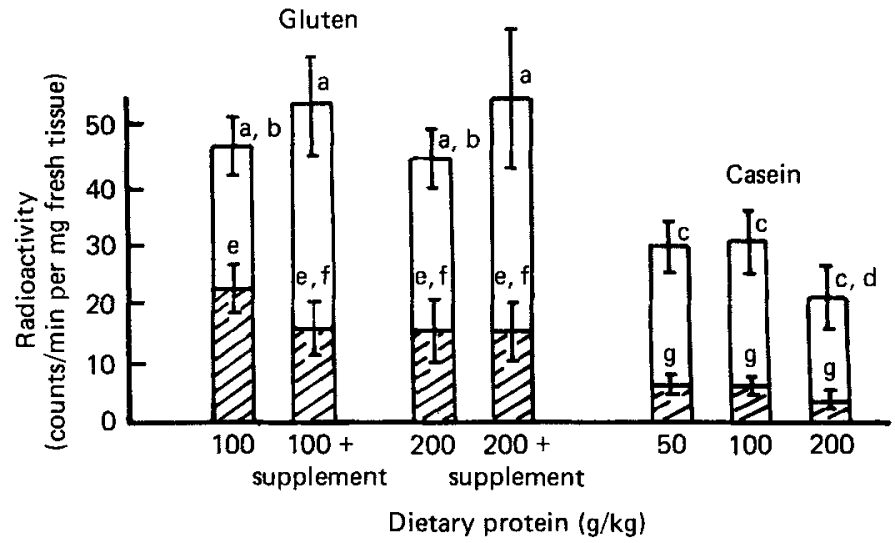

Fig. 1. The effect of dietary wheat gluten on the incorporation of $\left[1-{ }^{14} \mathrm{C}\right]$ acetate into liver lipids in counts/min per $\mathrm{mg}$ fresh tissue. Total lipids, $(\square)$; cholesterol, $(\boxminus)$. The results are mean values with their standard errors represented by vertical bars for eight rats. Values of the same index not sharing a common superscript letter differed significantly $(P<0.05)$.

and cholesterol synthesis were observed in all the gluten-fed groups as compared with the casein-fed groups. It is of interest to note that the supplementation of the gluten diets with lysine and threonine did not remove this effect.

Serum and liver cholesterol and faecal excretion of cholesterol and bile acids

Table 2 summarizes the results obtained for the excretion of total lipids, cholesterol and bile acids and for liver and serum cholesterol concentrations. An increased faecal excretion of total lipids, cholesterol and bile acids was found in all the groups fed on either gluten 
Table 2. Faecal excretion of cholesterol and bile acids and concentrations of serum and liver cholesterol of rats given gluten or casein diets for $21 \mathrm{~d}$

(Mean values with their standard errors for eight rats per dietary group)

\begin{tabular}{|c|c|c|c|c|c|c|c|c|c|c|}
\hline \multirow{3}{*}{$\begin{array}{l}\text { Dietary protein } \\
(\mathrm{g} / \mathrm{kg})\end{array}$} & \multicolumn{6}{|c|}{ Faecal excretion (mg/kg body-wt per $48 \mathrm{~h}$ ) } & \multirow{2}{*}{\multicolumn{2}{|c|}{$\begin{array}{l}\text { Serum } \\
\text { cholesterol } \\
(\mathrm{mg} / \mathrm{l})\end{array}$}} & \multirow{2}{*}{\multicolumn{2}{|c|}{$\begin{array}{c}\text { Liver } \\
\text { cholesterol } \\
(\mathrm{mg} / \mathrm{g} \text { fresh wt) }\end{array}$}} \\
\hline & \multicolumn{2}{|c|}{ Total lipids } & \multicolumn{2}{|c|}{ Cholesterol } & \multicolumn{2}{|c|}{ Bile acids } & & & & \\
\hline & Mean & $\mathrm{SE}$ & Mean & $\mathbf{S E}$ & Mean & SE & Mean & SE & Mean & $\mathbf{S E}$ \\
\hline \multicolumn{11}{|l|}{ Gluten: } \\
\hline 100 & $963^{b c}$ & 90 & $120^{\mathrm{bc}}$ & 13 & $56^{\mathrm{bc}}$ & 8 & $604^{a b}$ & 32 & $2 \cdot 9^{\mathrm{a}}$ & $0 \cdot 1$ \\
\hline $100+$ supplement* & $798^{\mathrm{cd}}$ & 40 & $95^{\mathrm{b}}$ & 7 & $44^{b}$ & 3 & $641^{\mathrm{ab}}$ & 44 & $2 \cdot 8^{\mathrm{a}}$ & $0 \cdot 1$ \\
\hline 200 & $1095^{b}$ & 70 & $155^{\mathrm{c}}$ & 13 & $57^{\mathrm{bc}}$ & 7 & $588^{\mathrm{ab}}$ & 33 & $2 \cdot 6^{\mathrm{a}}$ & 0.3 \\
\hline $200+$ supplement $\uparrow$ & $860^{\mathrm{ed}}$ & 40 & $102^{\mathrm{b}}$ & 11 & $41^{b}$ & 4 & $609^{a b}$ & 40 & $2 \cdot 5^{\mathrm{a}}$ & $0 \cdot 2$ \\
\hline \multicolumn{11}{|l|}{ Casein: } \\
\hline 50 & $1179^{b}$ & 135 & $94^{b}$ & 11 & $47^{\mathrm{b}}$ & 5 & $556^{\mathrm{a}}$ & 51 & $3 \cdot 6^{b}$ & $0 \cdot 3$ \\
\hline 100 & $637^{\mathrm{a}}$ & 40 & $59^{\mathrm{a}}$ & 8 & $20^{\mathrm{a}}$ & 4 & $789^{\mathrm{d}}$ & 20 & $3 \cdot 0^{\mathrm{a}}$ & $0 \cdot 1$ \\
\hline 200 & $578^{\mathrm{a}}$ & 46 & $52^{\mathrm{a}}$ & 5 & $26^{a}$ & 4 & $691^{\mathrm{bc}}$ & 53 & $2 \cdot 6^{a}$ & $0 \cdot 2$ \\
\hline
\end{tabular}

a, b, c, d Values in the same vertical column not sharing a common superscript letter differed significantly. $(P<0.05)$.

* Supplemented with $9 \mathrm{~g} \mathrm{~L}$-lysine hydrochloride and $2.8 \mathrm{~g} \mathrm{~L}$-threonine $/ \mathrm{kg}$.

† Supplemented with $6.5 \mathrm{~g}$ L-lysine hydrochloride and $0.3 \mathrm{~g} \mathrm{~L}$-threonine $/ \mathrm{kg}$.

or supplemented gluten diets as compared with the respective excretion observed in the rats fed on diets containing 100 or $200 \mathrm{~g}$ casein $/ \mathrm{kg}$. The concentrations of lipids, cholesterol and bile acids found in the faeces of the rats fed on the $50 \mathrm{~g}$ casein $/ \mathrm{kg}$ diet were very similar to those of the rats of the gluten-fed groups, and were significantly different from the respective concentrations found in the other casein-fed groups. Parallel to these increased excretions, all the gluten-fed rats as well as the animals fed on the $50 \mathrm{~g}$ casein $/ \mathrm{kg}$ diet exhibited lower levels of serum cholesterol compared with the rats fed on 100 and $200 \mathrm{~g}$ casein $/ \mathrm{kg}$ diets.

Similar liver cholesterol concentrations were found for all the groups except for the group given $50 \mathrm{~g}$ casein $/ \mathrm{kg}$ diet, which exhibited a significantly higher hepatic cholesterol level.

\section{DISCUSSION}

The hypocholesterolaemic effect of wheat gluten was observed in all the groups fed on the diets containing this protein, when compared with the groups fed on 100 and $200 \mathrm{~g}$ casein $/ \mathrm{kg}$ diets. The low levels of blood cholesterol were accompanied by increased faecal excretion of cholesterol and bile acids which were previously considered responsible for the reduced blood cholesterol levels in animals fed on diets containing wheat gluten (Einav et al. 1981) and soya-bean protein (Fumagalli et al. 1978; Nagata et al. 1980). With respect to the rats fed on the $100 \mathrm{~g}$ gluten $/ \mathrm{kg}$ diet, these findings could in part be attributed to the malnourished state of these animals since similar observations were apparent in the group fed on the $50 \mathrm{~g}$ casein $/ \mathrm{kg}$ diet. However, some other factors in the gluten itself must be the predominant cause of this alteration in cholesterol metabolism, since rats fed on the $200 \mathrm{~g}$ gluten $/ \mathrm{kg}$ diet exhibited even higher cholesterol and bile acid excretion along with an improved growth performance. The hypocholesterolaemic nature of the gluten was not removed by lysine and threonine supplementation. This is in accordance with the results obtained by Nagata et al. (1981) and by Sugano et al. (1982), who reported that the addition 
of lysine to soya-bean protein did not modify the intrinsic effect of this protein on serum cholesterol and on faecal steroid excretion.

The enhanced incorporation of acetate into hepatic total lipids and into cholesterol, observed with the gluten-fed rats as compared with the casein-fed rats, was not altered when the gluten was supplemented with lysine and threonine. This further substantiates the hypothesis that some factors in the gluten other than its inferior protein quality have a crucial effect on cholesterol metabolism.

The reduced acetate incorporation into liver cholesterol found with the rats fed on the $50 \mathrm{~g}$ casein $/ \mathrm{kg}$ diet, despite the low level of blood cholesterol and high faecal cholesterol and bile acids excretion, could be related to the accumulation of cholesterol in the livers of these animals. Accumulation of cholesterol in various mammalian cells was shown by in vitro studies (Ott et al. 1981) to suppress cholesterol biosynthesis through reduction of the activity of hydroxymethylglutaryl-CoA reductase $(E C 1.1 .1 .88)$, the rate-limiting enzyme in cholesterol biosynthesis. No liver cholesterol accumulation was evident with the other groups. Hepatic cholesterol accumulation which resulted in enhanced faecal excretion of cholesterol and bile acids was also shown by Leelama $e t$ al (1978) with rats fed on a $50 \mathrm{~g}$ casein $/ \mathrm{kg}$ diet. Such accumulation could be related to interference in cholesterol transport due to reduced low-density lipoprotein (LDL) biosynthesis as was found for rats fed on a $60 \mathrm{~g}$ casein $/ \mathrm{kg}$ diet (Seaking \& Waterlow, 1972). The impairment in hepatic cholesterol transport is probably the main reason for the hypocholesterolaemia induced by protein malnutrition. No interference in hepatic secretion and transport of cholesterol was indicated in rats fed on diets containing $100 \mathrm{~g}$ gluten $/ \mathrm{kg}$ (Einav et al. 1981). With respect to the various gluten-fed groups in the present study the results are in accordance with this earlier finding. Thus, the hypocholesterolaemic effect of wheat gluten is related to increased turnover of cholesterol as expressed by enhanced cholesterol biosynthesis and increased cholesterol and bile acid excretion and is not affected by the dietary levels of lysine and threonine.

The exact mechanism by which wheat gluten affects cholesterol metabolism is unclear, but some important observations should be mentioned in this respect. Higher levels of high-density lipoprotein (HDL) were found in rats fed on wheat gluten and soya-bean protein compared with animals fed on casein-containing diets (Mokady \& Liener, 1982). It is regarded that one of the major roles of $\mathrm{HDL}$ is to remove cholesterol from peripheral tissues and to transport it to the liver for disposal (Miller \& Miller, 1975). Furthermore, hypercholesterolaemia observed in rabbits fed on casein-containing diets was accompanied by a decrease in hepatic LDL receptors (Chao et al. 1982). This might have contributed to the decreased clearance of plasma cholesterol and to the reduction in biliary output.

The components of wheat gluten and of other plant-protein preparations which are responsible for their hypocholesterolaemic effects have not yet been identified. Numerous studies showed that plasma cholesterol was affected by dietary amino acid composition (West et al. 1983; Sautier et al, 1983). However, the relevance of these studies to the amino acid composition of plant proteins and the role of such amino acid patterns in controlling blood cholesterol levels is unclear. In this respect one should not eliminate the possibility that constituents other than amino acids which are associated with plant proteins, such as unavailable carbohydrates, may also contribute to the hypocholesterolaemic effects of plant proteins.

\section{REFERENCES}

Association of Official Agricultural Chemists (1970). Methods of Anatysis, p. 800. Washington, DC: Association of Official Agricultural Chemists.

Balogun, E. A., Balogun, O. O. \& Oduta, A. A. (1982). IRCS Medical Science 10, 643-644.

Chao, Y., Yamin, T. T. \& Alberts, A. W. (1982). Journal of Biological Chemistry 257, 3623-3627.

Dixon, W. J. (1971). BMD Biomedical Computer Program. Berkeley: University of California Press. 
Einav, P., Mokady, S. \& Cogan, U. (1981). Nutrition Reports International 24, 1001-1007.

Folch, J., Lees, M. \& Sloane-Stanley, G. H. (1957). Journal of Biological Chemistry 226, 497-505.

Fumagalli, R., Paoletti, R. \& Howard, A. N. (1978). Life Science 22, 947-955.

Kritchevsky, D. (1979). Journal of American Oil Chemists' Society 56, 135-146.

Leelama, S., Mennon, P. V. G. \& Kurup, P. A. (1978). Indian Journal of Experimental Biology 16, $29-35$.

Miller, G. J. \& Miller, N. E. (1975). Lancet i, 16-19.

Mokady, S. \& Einav, P. (1978). Nutrition and Metabolism 22, 181-189.

Mokady, S. \& Liener, I. E. (1982). Annals of Nutrition and Metabolism 26, 138-144.

Nagata, Y., Imaizumi, K. \& Sugano, M. (1980). British Journal of Nutrition 44, 113-121.

Nagata, Y., Tanaka, K. \& Sugano, M. (1981). British Journal of Nutrition 45, 233-241.

Ott, D. B., Paul, N. S. \& Lachance, A. (1981). American Journal of Clinical Nutrition 34, 2295-2306.

Rama-Rao, P. B., Metta, V. C. \& Johnson, B. C. (1959). Journal of Nutrition 60, 387-391.

Rudel, L. L. \& Morris, D. M. (1973). Journal of Lipid Research 14, 364-366.

Sautier, C., Dieng, K., Flament, C., Doucet, C., Suquet, J. P. \& Lemmonier, D. (1983). British Journal of Nutrition 49, 313-319.

Seaking, A. \& Waterlow, J. C. (1972). Biochemistry Journal 129, 793-798.

Singer, E. J. \& Fitschen, W. H. (1961). Analytical Biochemistry 2, 292-308.

Sugano, M., Ishiwaki, N., Nagata, Y. \& Imaizumi, K. (1982). British Journal of Nutrition 48, $211-221$.

Tripathy, K., Lotero, H. \& Bolanos, O. (1970). American Journal of Clinical Nutrition 23, 1160-1168.

West, C. E., Beynen, A. C. Terpestra, A. H. M., Scholz, K. E., Carrol, K. K. \& Woodward, C. J. H. (1983). Atherosclerosis, 46, 253-256. 